\title{
Regional development and regional policy in the Czech Republic after 1989
}

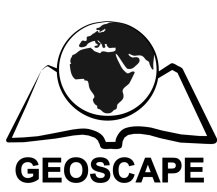

\author{
René Wokoun ${ }^{1 *}$ - Milan Viturka ${ }^{2}$ \\ ${ }^{1}$ Department of Regional Development and Public \\ Administration, Faculty of Social and Economic Studies, J. E. \\ Purkyne University, Moskevská 54, 40096 Ústí nad Labem, \\ Czech Republic \\ * rene.wokoun@ujep.cz \\ ${ }^{2}$ Faculty of Economics and Administration, Masaryk University, \\ Lipová 41, 60200 Brno, Czech Republic
}

\begin{abstract}
The major aim of the paper is to summarize the main paths of regional development in the Czech Republic during the period of political, economical and societal transition using the statistical data and own survey at the country level. Following this summary, we aim at differentiation of regional developmental paths at individual hierarchical levels. Our analyses shows that structured assessment of quality of socio-economic environment at the regional respectively meso-regional level provides the necessary information needed for creation and implementation of effectively decentralized regional policy.
\end{abstract}

Key words: regional development; regional policy; period of transition; Czech Republic

Received: 17 Apr 2014 - Accepted: 8 Dec 2014

\section{Introduction}

Developmental and hierarchical differentiation of social systems is in accordance with the general rules of evolution characterized by the constant creation and overcoming of differences respectively space-time blending of processes of polarization and integration (see, e.g., Hampl 1996; Hampl 2010).

From the regionalistic perspective we usually talk about divergence or convergence trends in regional development. The main bearer of divergence is generally considered the private sector and the main bearer of the convergence is the public sector, whose major role includes the regulation of negative regional impacts generated by the operation of market mechanisms (in this context, it is necessary to draw attention to the fact that in accordance with system theory, a permanent dominance of one of the above tendency would lead to a gradual degradation of the entire system). The growing interest in the issue of regional development (represented mainly by questions such as what are the main factors of regional development, why some regions develop faster than others or why social differences persist between regions) causes a corresponding demand for innovative theoretical and methodological approaches to regional research and complementary integration in the context of general economic theory.

This development logically corresponds to the growing importance of regional components of economic policy (regional policy), which is in the Czech Republic formed by returning to the "natural" trajectory of economic development and accession to the European Union. In our opinion it is a relevant response to the deepening globalization and structural change in the economy, which in addition to the positive (e.g. price) effects has on the other hand increased risks for future development. Adequate concepts of economic policy, represented by economic, social and territorial cohesion of the European Union, are therefore increasingly linked to the shift from direct support of declining industries to 
indirect support of social development by improving the quality of the business and social environment (with an emphasis on harmonious and sustainable regional development).

\section{Regional development in the Czech Republic}

Quite a considerable dynamic regional development in the Czech Republic after the "Velvet Revolution" in 1989 was determined by the major geopolitical changes, of which it is necessary to specify the particular division of Czechoslovakia in 1993 and the accession of the Czech Republic into the European Union in 2004. While in the first case, the corresponding impacts may be considered as very limited from a regional perspective (Moravian-Slovak border), in the second case it was a versatile deepening development tendencies which started with market transformation of the Czech economy (land modified growing influx of foreign investments). In terms of the achieved economic growth, the most important trends at the regional level respectively NUTS 3 regions are considered (as in the case of most other postcommunist Central European countries) constitution of an East-West gradient characterized by decline in the economic performance of regions to the east and the distribution of 14 regions in two subgroups: the specific Region of the Capital City Prague and the rest of Czech and Moravian Regions.

The uniqueness of the Prague region is the fact that it is the only region with above average GDP per capita relative to the average for the whole country, which also reaches the fastest rate of economic growth (in this respect it is followed by Středočeský region and Jihomoravský region, on the other end of the scale you will find a Karlovy Vary Region). In accordance with this fact the Prague region (possessing nearly one quarter of the total GDP) is of course the main carrier of divergence tendencies at the given hierarchical level. If we evaluate the divergence tendencies within the reduced set of regions without Prague they are logically much less pronounced (see Table 1). The clearest evidence of west-east gradient is the fact that six regions with the highest levels of GDP per capita in the eastern part of the country are located just in
Jihomoravský Region (in this context, however, it is necessary to draw attention to certain inadequacy of regional GDP figures given the methodology used which document data on GDP per capita in the Středočeský Region for the year 1995).

For the assessment of adequate regional capacity to constantly adapt to general and specific development trends generated from economic development, the unemployment rate is generally considered to be the most concise indicator (from a broader perspective this indicator can in conjunction with the indicator of job vacancies understood as an indicator of the use of human resources, be regarded as the most important factor of economic development). The data in the Table 2 shows that after 1995 there was on average approximately three-fold increase in the level of registered unemployment in all regions (bank privatization in 1997 is generally considered to be the trigger mechanism which ended the so-called controversial banking socialism).

From the perspective of the individual regions there is a group of three structurally affected regions which was practically formed at the very beginning of the economic transformation (with a strong presence of the economically sensitive sectors such as mining, metallurgical and textile industry and agriculture) with consistently high levels of unemployment - Ústecký, Moravskoslezký and Olomoucký region.

It is useful to note that the constitution of the long-term imbalances between demand and supply of labor stimulates emigration of younger and more educated population age groups with negative impacts on regional competitiveness. On the other hand, economically exceptionally adaptable regions with low levels of unemployment, in addition to specific regions of Prague with the lowest unemployment, are Jihočeský, Královehradecký and Plzeňský region and after 2000 even Středočeský region (these regions logically showed an above-average level of creation of new jobs). After the onset of the recession in 2008, there was a significant increase in cyclical unemployment, which due to the higher initial base of structural unemployment, 
recorded the lowest increase in the most affected

regions of Moravskoslezký and Ústecký regions.

Tab. 1 - Development of GDP per capita (in CZK) (b. c). Source: Czech statistical office.

\begin{tabular}{lllllrrr} 
Region & $\mathbf{1 9 9 5}$ & $\mathbf{2 0 0 0}$ & $\mathbf{2 0 0 5}$ & $\mathbf{2 0 1 0}$ & $\mathbf{2 0 0 0 / 1 9 9 5}$ & $\mathbf{2 0 0 5 / 2 0 0 0}$ & $\mathbf{2 0 1 0 / 2 0 0 5}$ \\
\hline Praha & 249665 & 432293 & 639470 & 771773 & 1.73 & 1.48 & 1.21 \\
Středočeský & 131317 & 211562 & 277088 & 318849 & 1.61 & 1.31 & 1.15 \\
Jihočeský & 141158 & 206061 & 275950 & 305996 & 1.46 & 1.34 & 1.11 \\
Plzeňský & 142950 & 205760 & 288451 & 319564 & 1.44 & 1.40 & 1.11 \\
Karlovarský & 144049 & 192638 & 237537 & 260065 & 1.34 & 1.23 & 1.09 \\
Ústecký & 142816 & 182863 & 250381 & 291977 & 1.28 & 1.37 & 1.17 \\
Liberecký & 135680 & 199418 & 252791 & 275701 & 1.47 & 1.27 & 1.09 \\
Královéhradecký & 138963 & 209863 & 264873 & 314992 & 1.51 & 1.26 & 1.19 \\
Pardubický & 132769 & 190196 & 249765 & 291190 & 1.43 & 1.31 & 1.17 \\
Vysočina & 125534 & 184488 & 254853 & 292343 & 1.47 & 1.38 & 1.15 \\
Jihomoravský & 140850 & 203544 & 274819 & 340397 & 1.45 & 1.35 & 1.24 \\
Olomoucký & 124737 & 175783 & 229065 & 274326 & 1.41 & 1.30 & 1.20 \\
Zlínský & 128080 & 185019 & 245280 & 301494 & 1.44 & 1.33 & 1.23 \\
Moravskoslezský & 130543 & 172735 & 258615 & 304290 & 1.32 & 1.50 & 1.18 \\
Czech Republic & $\mathbf{1 4 8 4 5 7}$ & $\mathbf{2 2 0 9 4 9}$ & $\mathbf{3 0 4 4 7 8}$ & $\mathbf{3 6 0 4 4 4}$ & $\mathbf{1 . 4 9}$ & $\mathbf{1 . 3 8}$ & $\mathbf{1 . 1 8}$
\end{tabular}

Tab. 2 - Development of unemployment rate. Sources: Ministry of Labour and Social Affairs, Czech statistical office.

\begin{tabular}{|c|c|c|c|c|c|c|}
\hline Region & 1995 & 2000 & 2005 & 2010 & 2000/1995 & $2010 / 2005$ \\
\hline Praha & 0.29 & 3.42 & 3.25 & 4.07 & 11.79 & 1.25 \\
\hline Středočeský & 2.57 & 6.80 & 6.25 & 7.73 & 2.65 & 1.24 \\
\hline Jihočeský & 1.99 & 5.82 & 6.69 & 8.50 & 2.92 & 1.27 \\
\hline Plzeňský & 2.19 & 6.47 & 6.45 & 8.25 & 2.95 & 1.28 \\
\hline Karlovarský & 2.12 & 8.02 & 10.28 & 11.39 & 3.78 & 1.11 \\
\hline Ústecký & 5.79 & 16.15 & 15.41 & 13.90 & 2.79 & 0.90 \\
\hline Liberecký & 2.45 & 6.44 & 7.73 & 10.54 & 2.63 & 1.36 \\
\hline Královéhradecký & 1.99 & 5.89 & 7.33 & 8.37 & 2.96 & 1.14 \\
\hline Pardubický & 2.66 & 7.87 & 8.35 & 9.87 & 2.96 & 1.18 \\
\hline Vysočina & 3.39 & 7.48 & 8.23 & 10.73 & 2.21 & 1.30 \\
\hline Jihomoravský & 2.92 & 9.35 & 10.21 & 10.87 & 3.20 & 1.06 \\
\hline Olomoucký & 4.31 & 11.87 & 10.85 & 12.48 & 2.75 & 1.15 \\
\hline Zlínský & 2.40 & 8.14 & 9.27 & 10.74 & 3.39 & 1.16 \\
\hline Moravskoslezský & 5.07 & 15.13 & 14.23 & 12.36 & 2.98 & 0.87 \\
\hline Czech Republic & 2.93 & 8.78 & 8.88 & 9.57 & 3.00 & 1.08 \\
\hline
\end{tabular}

It is necessary to add that their statistical monitoring is since 2005 based on new methodologies and subsequent figures are therefore not comparable with previous data.

With regard to the demographic development (Table 3 ) of the region, slightly decreasing trend in the reference period was characteristic for most of them. This trend was of course replaced by a slightly increasing trend at the end (from a structural point of view it is useful to draw particular attention to the general worsening of the age structure of the population). Distinctly different developmental tendency was found particularly in the Středočeský region, which showed increasing trends (overall increase of 150 thousand citizens). The main reason is of course the general attractiveness of Prague, which in this case manifests itself in interaction with suburbanization processes. This corresponds to above-average migration attractiveness of the Středočeský region and Prague, manifested by high positive values of net migration, which in the period 2005-2010 reached a level of $10 \%$ in relation to the number of inhabitants (from other 
regions in this context we can refer to a distinct positive trend in the Jihočeský, Liberecký and Plzeňský region). Moravskoslezký Region is also very specific. It showed negative trends throughout the period - overall decline in population reached 50 thousand here (consistently negative migration balance was also found even in the Karlovy Vary region).

Tab. 3 - Development of the population in thousands. Source: Czech statistical office.

\begin{tabular}{lrrrrrrr} 
Region & \multicolumn{1}{c}{$\mathbf{1 9 9 5}$} & \multicolumn{1}{c}{$\mathbf{2 0 0 0}$} & \multicolumn{1}{c}{$\mathbf{2 0 0 5}$} & \multicolumn{1}{c}{$\mathbf{2 0 1 0}$} & $\mathbf{2 0 0 0 / 1 9 9 5}$ & $\mathbf{2 0 0 5 / 2 0 0 0}$ & $\mathbf{2 0 1 0 / 2 0 0 5}$ \\
\hline Praha & 1212655 & 1183900 & 1176116 & 1251726 & 0.98 & 0.99 & 1.06 \\
Středočeský & 1107529 & 1113149 & 1150128 & 1257194 & 1.01 & 1.03 & 1.09 \\
Jihočeský & 627180 & 625991 & 626766 & 637910 & 1.00 & 1.00 & 1.02 \\
Plzeňský & 556072 & 551650 & 550371 & 572023 & 0.99 & 1.00 & 1.04 \\
Karlovarský & 305094 & 304599 & 304587 & 307619 & 1.00 & 1.00 & 1.01 \\
Ústecký & 825628 & 826992 & 822977 & 835796 & 1.00 & 1.00 & 1.02 \\
Liberecký & 428920 & 429113 & 428268 & 439483 & 1.00 & 1.00 & 1.03 \\
Královéhradecký & 554163 & 551297 & 547849 & 554296 & 0.99 & 0.99 & 1.01 \\
Pardubický & 510677 & 508542 & 505553 & 516776 & 1.00 & 0.99 & 1.02 \\
Vysočina & 523201 & 521019 & 510000 & 514800 & 1.00 & 0.98 & 1.01 \\
Jihomoravský & 1141888 & 1136689 & 1130282 & 1152765 & 1.00 & 0.99 & 1.02 \\
Olomoucký & 641957 & 641554 & 638981 & 641661 & 1.00 & 1.00 & 1.00 \\
Zlínský & 601215 & 598057 & 590447 & 590459 & 0.99 & 0.99 & 1.00 \\
Moravskoslezský & 1294580 & 1279951 & 1251767 & 1244739 & 0.99 & 0.98 & 0.99 \\
Czech Republic & $\mathbf{1 0 3 3 0 7 5 9}$ & $\mathbf{1 0 2 7 2 5 0 3}$ & $\mathbf{1 0 2 3 4 0 9 2}$ & $\mathbf{1 0 5 1 7 2 4 7}$ & $\mathbf{0 . 9 9}$ & $\mathbf{1 . 0 0}$ & $\mathbf{1 . 0 3}$
\end{tabular}

If we further focus on regional evaluation of the achieved level of social development and its sustainability it is necessary to move the primary focus from the above commented analysis of growth tendency towards a broader analysis of development foresight (development is more comprehensive term than growth regions because the main emphasis on the transformation of quantitative changes instead of qualitative changes and their subsequent propagation through the division of labor in any interaction with the activities of public administration). Long-term sustainability of regional development is in direct proportion with the deepening respectively restoring of internal (stimulation of harmonious relations within social systems) and external (regulation of disharmonious relationships of social and natural systems) balance which reflects trends in the economic, social and, to some extent, the environmental components of social development. For this purpose, the Department of Regional Economics and Administration ESF
MU developed the original model of regional evaluation of the quality of the business environment (KPP/QBE) and quality of the social environment (KSP/QSE).

A comprehensive synthesis of the results of the three analyzes KPP (including related sub-analysis of the use of human resources/ VLZ and innovation potential of companies/ IPF) conducted between 1996 to 2010 and supplemented by analysis KSP in the last cycle allowed us to establish a first spatial model generalizing the results of Regional Development of the Czech Republic. The developed analytical models of evaluation of KPP and KSP always include 16 selected factors which reflect the land bound preferences of companies and the general public, which determine the long-term socioeconomic development of the individual meso regions/regions, as well as elementary micro regions which are identified with the territorial districts of municipalities with extended competence of the third degree (Viturka et al, 2010; Viturka et al. 2013). Regarding the mutual 
relations of KPP and KSP balanced position was found in half of the regions (Středočeský, Jihočeský, Karlovarský, Liberecký, Olomoucký, Vysočina and Zlínský regions). The developed models respect the developmental patterns and closely linked hierarchical differentiation of social systems, whose most important spatial manifestation is constitution of poles and axis development axes (Table 4; Fig. 1).

Tab. 4 - Regional value of KPP and KSP. Source: own research.

\begin{tabular}{lrrrr} 
Region & \multicolumn{1}{l}{ KPP } & KPP centers & \multicolumn{1}{l}{ KSP } & KSP centers \\
\hline Praha & 1.16 & $\mathrm{X}$ & 2.50 & X \\
Středočeský & 2.65 & 2.03 & 2.90 & 2.44 \\
Jihočeský & 2.86 & 1.98 & 2.64 & 2.31 \\
Plzeňský & 2.77 & 1.68 & 2.91 & 2.56 \\
Karlovarský & 2.90 & 2.19 & 3.31 & 3.38 \\
Ústecký & 3.05 & 2.35 & 3.47 & 3.09 \\
Liberecký & 2.79 & 2.02 & 2.93 & 2.53 \\
Královéhradecký & 2.86 & 1.88 & 2.87 & 2.56 \\
Pardubický & 2.94 & 1.81 & 2.74 & 2.31 \\
Vysočina & 3.02 & 2.16 & 2.73 & 2.44 \\
Jihomoravský & 2.78 & 1.54 & 2.93 & 2.56 \\
Olomoucký & 3.19 & 2.37 & 3.03 & 2.50 \\
Zlínský & 3.29 & 2.43 & 2.89 & 2.50 \\
Moravskoslezský & 3.27 & 2.33 & 3.40 & 3.50 \\
Czech Republic & $\mathbf{2 . 7 4}$ & $\mathbf{1 . 1 6}$ & $\mathbf{2 . 9 5}$ & $\mathbf{2 . 5 0}$
\end{tabular}

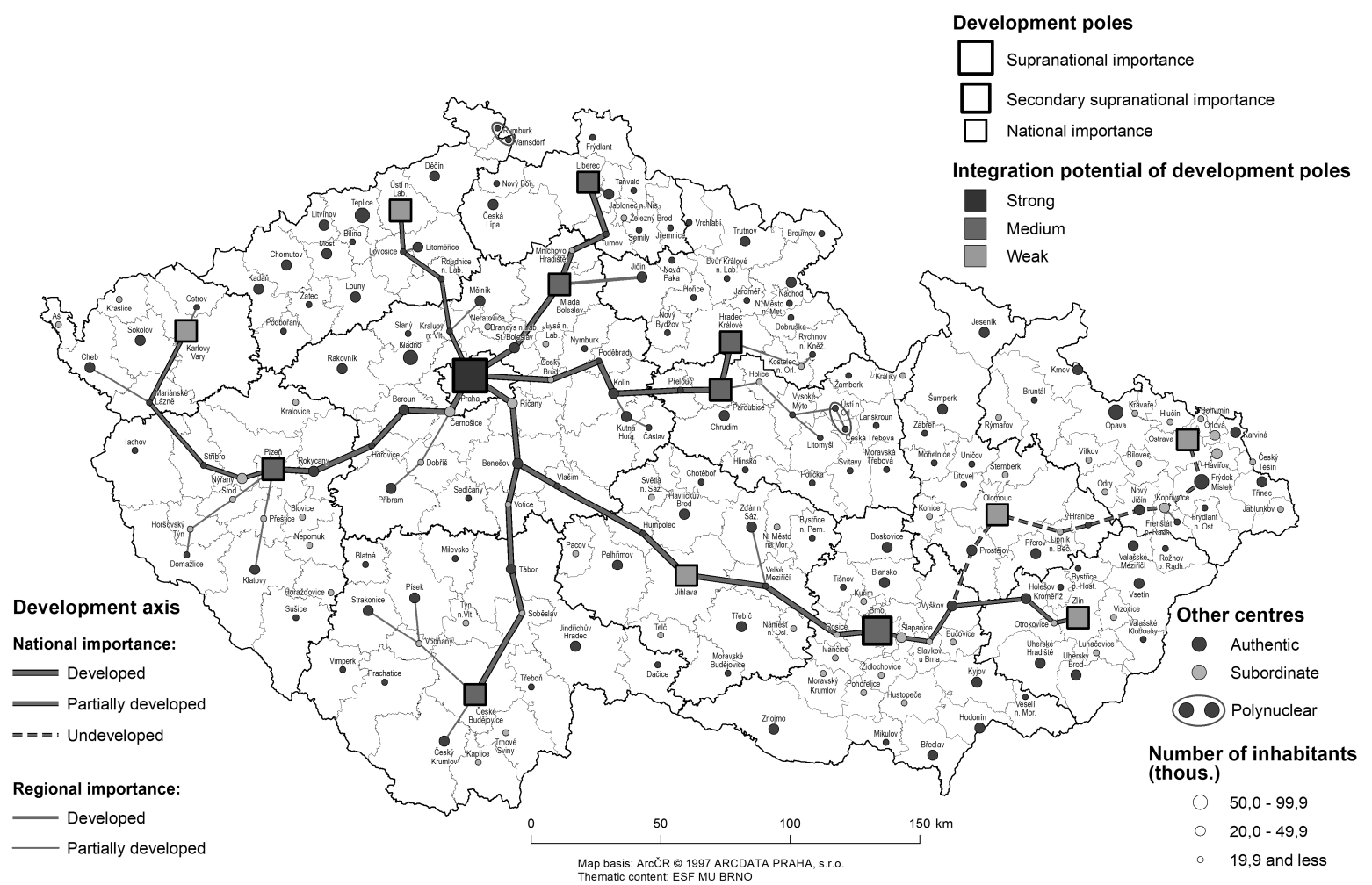

Fig. 1 - Dynamic model of development potential of regions in the Czech Republic. Source: own processing. 
These models are unlike earlier models allow the exact identification: KPP values above average (in interaction with IPF and functional position in the system of territorial administration) in the case of development poles and significant positive deviation of real values from the theoretical values of KPP which correspond to population size of micro region (in interaction with VLZ) in the case of development axes. Development poles (which are in the Czech Republic almost exclusively regional cities) undoubtedly represent a major holders of agglomeration benefits and thus the creation of economic and social effects (accumulated in regional KPP and KSP) and axis of development the main channels of spread into space - nine development axes of national importance and sixteen development axes of regional significance were defined within the last processed case studies of the Czech Republic. The associated deepening of the territorial division of labor and the increasing interconnectedness of regions are changing the ways of achieving optimal resource allocation and expands the boundaries of production possibilities of firms and accordingly increases the potential for development of regional structures located in contact with the development axes. Discovered facts confirm the crucial role of development poles as the main organizers of economic and social interactions unfolding of their integration potential.

KPP and KSP evaluation models constitute the fundamental components of the original integrative theory of sustainable regional development, which illustrates the effect of the patterns of spatial differentiation generating fundamental conditions for long-term regional development in an open economy. The logic of this theory can be systematically described as follows (Viturka 2011). Improving the overall quality of the business environment stimulates business development and hence a concentration of domestic and foreign capital with a positive impact on the development of employment and the formation of innovation. The main spatial manifestation of these intricately structured processes is economic differentiation of regions, which can be understood as a comprehensive reflection of the critical processes associated with their existing development. This continuous ongoing differentiation in interaction with social and some natural factors determines the hierarchical position of the settlements and on this basis constituted regional systems (including their level of complexity). Real intensity of use of socio-economic potential of individual regions is then derived from the success of specialization of production and services (taking into account the available objective and subjective affecting factors) and the unfolding territorial division of labor. An integral part of the division of labor is the creation of nodal regions (forming a microregional hierarchical level) which, in accordance with the integration processes of higher level form the basic building blocks of spatial systems, poles and development axes (forming a hierarchical meso-regional level) as one of the decisive factors of internal integrity of the parent macro-region i.e. the state. The positive synergy effects generated by these processes increase the mobility of production factors, accelerate the transfer of knowledge, support the creation of business networks and clusters and significantly contribute to the deepening of the regional integration of the economy with positive effects on regional competitiveness and sustainability of regional development. The results of modeling of spatial relations between KPP and KSP in line with many other analyzes (e.g., Harvey 1985) confirm that achieving of the desired state of dynamic equilibrium of social systems depends to a significant extent on institutional control of adverse impacts on quality of life induced by market mechanisms. From a social point of view and also in general we can say that without balanced social relations we can hardly achieve balanced economic growth and the balance between economic development and quality of life. That is why the balance is necessary for sustainability of regional development. Consistency of the created theory of integration is confirmed by the following empirically verified facts:

- strong positive correlation of KPP and GDP,

- positive links of KPP with VLZ and IPF, 
-positive links of KSP and migration

attractiveness,

- utility of KPP and KSP models for the exact definition of poles and development axes,

- proven correlation between KPP and KSP (with less intensity) and important position of the micro regions.

These facts allow us to receive important conclusion that structured assessment of quality of socio-economic environment at the regional respectively meso-regional level provides the necessary information needed for creation and implementation of effectively decentralized regional policy.

\section{References}

Hampl M et al. (1996) Geografická organizace společnosti a transformační procesy $\mathrm{v}$ České republice. Prírodovědecká fakulta Univerzity Karlovy, Praha.

Hampl M (2010) Regionální diferenciace společnosti, Geografie 1: 1-20.

Harvey J (1985) The urbanization of capital: studies in the history and theory of capitalist urbanization. J. Hopkins University Press, Baltimore.

Viturka M et al. (2010) Kvalita podnikatelského prostředí, regionální konkurenceschopnost a strategie regionálního rozvoje České republiky. Grada, Praha.

Viturka M (2011) Integrační teorie udržitelného regionálního rozvoje (představení a aplikace). Politická ekonomie 6: 794-809.

Viturka M, Wokoun R, Krejčová N, Tonev P, Žítek V (2013) The Regional Relationship between Quality of Business and Social Environment: Harmony or Disharmony? Ekonomika a management, 2: 22-40. 